\title{
INTEGRASI PAJAK DAN ZAKAT SEBAGAI SUMBER PEMBIAYAAN PEMBANGUNAN NASIONAL
}

\author{
Nur Hadiyati \\ Program Pascasarjana Fakultas Hukum Universitas Indonesia \\ Jl. Salemba Raya No. 4 Jakarta 10430 \\ E-mail : n.hadiyati @yahoo.co.id
}

\begin{abstract}
The state in carrying out his duties to achieve public welfare requires the costs described in the budget of state income and expenditure (APBN). Taxes are Indonesia's largest source of revenue, but currently have decreased. The government is aware of the potential of zakat as a source of national development financing. Then the idea emerged to integrate tax and zakat withdrawal. This study aims to provide an understanding regarding the formulation of the integration of tax and zakat starting from definition of tax and zakat, the use of tax and zakat, the institutional structure that is authorized to collect tax and zakat. The method used in this journal is normative legal research with primary and secondary legal material sources. There are three models with regard to the integration of zakat and taxes offered: (1) zakat and tax payments are two different things and cannot be put together; (2) the payment of zakat releases the obligation to pay taxes; and (3) zakat payments provide a reduction in the burden of tax payments. Integration of tax and zakat requires in-depth study.
\end{abstract}

\section{Keywords : Tax, Zakat, Finance, Development}

\begin{abstract}
Abstrak
Negara dalam menjalankan tugas dan fungsinya guna tercapainya kesejahteraan masyarakat membutuhkan biaya yang termaktub dalam anggaran pendapatan dan belanja negara (APBN). Pajak menjadi sumber penerimaan terbesar negara Indonesia, namun saat ini mengalami penurunan penerimaan. Pemerintah menyadari potensi dari zakat sebagai sumber pembiayaan pembangunan nasional. Maka kemudian muncul gagasan untuk mengintegrasikan penarikan pajak dan zakat. Penelitian ini bertujuan untuk memberikan pemahaman berkenaan dengan formulasi integrasi pajak dan zakat dimulai dari pengunaan yang diperoleh dari pemahaman berkenaan dengan pajak dan zakat sendiri serta struktur kelembagaan yang berwenang yang memerlukan kajian mendalam. Metode yang digunakan dalam jurnal ini adalah penelitian hukum normatif dengan sumber bahan hukum primer dan skunder. Terdapat tiga model berkaitan dengan integrasi zakat dan pajak yakni terdiri dari : (1) pembayaran zakat dan pajak menjadi dua hal yang berbeda sehingga harus dipisahkan; (2) pembayaran zakat melepaskan kewajiban membayar pajak; dan (3) pembayaran zakat memberikan pengurangan beban dalam pembayaran pajak. Pengintegrasian pajak dan zakat memerlukan kajian yang mendalam.
\end{abstract}




\section{Kata Kunci : Zakat, Pajak, Pembangunan, Keuangan}

\section{A. PENDAHULUAN}

Indonesia mengalami defisit atau penyusutan keuangan sampai dengan 31 Januari 2018 sebesar 37,4 triliun rupiah atau 11,4 persen dari perkiraan Tahun 2008 senilai total 325,9 triliun rupiah. Dengan demikian dibutuhkan inovasi terkait keuangan negara, salah satunya adalah dengan pengintegrasian pajak dan zakat sebagai sumber keuangan negara.

Zakat berpotensi besar sebagai sumber pembiayaan pembangunan nasional, Kementerian Agama akhir-akhir ini mewacanakan untuk dilakukan upaya penarikan zakat penghasilan dari gaji Aparatur Sipil Negara, apabila kebijakan ini diterapkan potensi dari zakat yang dikumpulkan mencapai 10 triliun rupiah setiap tahun ${ }^{1}$. Dari sisi penerimaan zakat sekarang hanya mencapai 6 triliun rupiah dari total potensi penerimaan zakat sebesar 217 triliun rupiah. Wacana ini sebenarnya bukanlah hal baru, sejak 2014 telah diterbitkan Instruksi Presiden Nomor 3 Tahun 2014 tentang optimalisasi pengumpulan zakat di Kementerian/ Lembaga, Sekretariat Jenderal Lembaga Negara, Sekretariat Jenderal Komisi Negara, Badan Usaha Milik Negara, Badan Usaha Milik Daerah Pemerintah Daerah, melalui Badan Amil Zakat Nasional atau Baznas. Terdapat potensi dari zakat sebagaimana diutarakan Sri Mulyani selaku Menteri Keuangan dimana potensi zakat di Indonesia mencapai 217 triliun rupiah, besarnya potensi tersebut setara dengan PNBP (penerimaan negara bukan pajak). Namun, hanya 2 persen yang mampu dikumpulkan melalui Baznas (Badan Amil Zakat Nasional) ${ }^{2}$.

Pajak sendiri diamanatkan pasca perubahan ketiga konstitusi Indonesia yakni dalam Pasal 23A Undang-Undang Dasar Negara Republik Indonesia Tahun 1945 "Pajak dan pungutan lain yang bersifat memaksa untuk keperluan negara diatur dengan undang-undang”. Pajak menjadi ujung tombak dalam pendapatan negara yakni sekitar $70 \%$ dari penerimaan negara. Hal ini sebagaimana diutarakan oleh Sri Mulyani selaku Menteri Keuangan, "tiga pembiayaan negara terbesar bersumber APBN, yaitu dari penerimaan perpajakan 1.498 triliun, Penerimaan negara bukan pajak 250 triliun, dan hibah 1,4 triliun"3.

Masyarakat memiliki pendapat pro dan kontra terhadap Integrasi pajak dan zakat, banyak hal yang harus diperhatikan berkenaan dengan operasional berkenaan dengan kebijakan penarikan zakat penghasilan dari gaji Aparatur Sipil Negara (ASN) menjadi menarik untuk memahami bagaimana zakat dan pajak secara berdampingan sebagai bagian tak terpisahkan

\footnotetext{
${ }^{1}$ Republika, "Ini Alasan Pemeirntah Pungut Langsung Zakat Gaji PNS Muslim", http://nasional.republika.co.id/berita/nasional/news-analysis/18/02/08/p3t4ig415-ini- alasan-pemerintahpungut-langsung-zakat-gaji-pns-muslim (Diakses pada 15/8/2018)

${ }^{2}$ Septian Deny, "Sri Mulyani Ingin Zakat Dikelola seperti Pajak", 2017 http://bisnis.liputan6.com/read/3068350/sri-mulyani-ingin-zakat-dikelola-sepertipajak, (Diakses pada 15/8/2018) ${ }^{3}$ Serambi News, "Pajak Sumber APBN Terbesar",2017, http://aceh.tribunnews.com/2017/08/12/pajak-sumberapbn-terbesar, (Diakses pada 15/8/2018)
} 
dalam sistem keuangan negara yang dapat dipergunakan untuk mencapai kemaslahatan bersama sebagaimana dicita-citakan dalam UUD NRI Tahun 1945.

\section{B. PEMBAHASAN}

\section{Pajak dan Zakat di Indonesia}

Berdasarkan Undang-Undang Nomor 16 Tahun 2009 tentang Ketentuan Umum dan Tata Cara Perpajakan menjelaskan bahwa yang dimaksud dengan "Pajak adalah kontribusi wajib kepada negara yang terutang oleh orang pribadi atau badan yang bersifat memaksa berdasarkan Undang-Undang dengan tidak mendapatkan imbalan secara langsung dan digunakan untuk keperluan negara bagi sebesar-besar kemakmuran rakyat. Maka kemudian selanjutnya penarikan pajak di Indonesia di atur dalam beberapa instrumen hukum yakni:

a. Undang-Undang Nomor 6 Tahun 1983 sebagaimana telah diubah menjadi UndangUndang Nomor 16 Tahun 2009 tentang Ketentuan Umum dan Tata Cara Perpajakan;

b. Undang-Undang Nomor 7 Tahun 1983 sebagaimana telah diubah menjadi UndangUndang Nomor 36 Tahun 2008 tentang Pajak Penghasilan;

c. Undang-Undang Nomor 8 Tahun 1983 sebagaimana telah diubah menjadi UndangUndang Nomor 42 Tahun 2009 tentang Pajak Pertambahan Nilai Barang dan Jasa dan Pajak Pertambahan Nilai dan Pajak Penjualan Barang Mewah;

d. Undang-Undang Nomor 12 Tahun 1985 sebagaimana telah diubah menjadi UndangUndang Nomor 12 Tahun 1994 tentang Pajak Bumi Dan Bangunan;

e. Undang-Undang Nomor 19 Tahun 1997 sebagaimana telah diubah menjadi UndangUndang Nomor 19 Tahun 2000 tentang Penagihan Pajak Dengan Surat Paksa;

f. Undang-Undang Nomor 13 Tahun 1985 tentang Bea Meterai;

g. Undang-Undang Nomor 14 Tahun 2002 tentang Pengadilan Pajak;

h. Undang-Undang Nomor 28 Tahun 2009 tentang Pajak Daerah dan Retribusi Daerah.

Pada awalnya bentuk peraturan berkenaan dengan pajak pada awal tahun 1984 dengan melakukan perubahan sistem perpajakan dari konsep Official Assesment menjadi Self Assesment System. Sebelumnya penarikan secara official assesment yakni sistem pemungutan pajak menjelaskan jumlah pajak yang terutang oleh wajib pajak dihitung dan ditetapkan oleh aparat pajak. Dalam sistem ini hutang pajak timbul bila telah ada ketetapan pajak dari aparat pajak, sehingga dalam hal ini wajib pajak bersifat pasif ${ }^{4}$. Pada Era sekarang telah berganti menjadi self assesment system yaitu Sistem pemungutan pajak bahwa wewenang penghitungan besaran pajak terutang wajib pajak ditentukan oleh aparat pajak, sehingga dengan sistem ini wajib pajak harus aktif untuk menghitung,

\footnotetext{
${ }^{4}$ Edy suprianto, Hukum Pajak Indonesia, Yogyakarta: Graha Ilmu , 2014, hlm 5.
} 
menyerahkan, dan melaporkan dengan benar kepada Kantor Pajak, tugas aparat pajak adalah melakukan pengawasan dan pembinaan pajak.

Sementara sistem With Holding Tax System yaitu Sistem pemungutan pajak yang menjelaskan jumlah pajak terutang dihitung oleh pihak ketiga artinya bukan dihitung oleh wajib pajak dan aparat pajak ${ }^{5}$. Self assessment system diberlakukan untuk memberikan kepercayaan yang sebesar-besarnya bagi masyarakat guna meningkatkan kesadaran dan peran masyarakat dalam menyetorkan pajaknya. Konsekuensinya, masyarakat harus benar-benar mengetahui tata cara perhitungan pajak dan segala sesuatu yang berhubungan dengan peraturan pemenuhan perpajakan ${ }^{6}$.

Di Indonesia pajak dikelompokkan menurut golongan, sifat, dan lembaga pemungutnya yang dijabarkan dalam gambar sebagai berikut :

\section{Gambar 1. Klasifikasi Pajak}

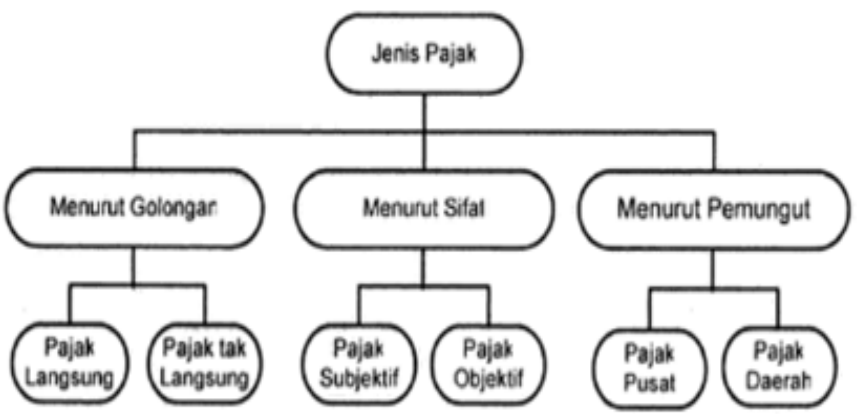

Seiring perkembangan waktu pajak masih memegang peranan penting dalam keuangan negara Indonesia yang dapat dilihat dari besarnya angka penerimaan dari pajak dalam pendapatan negara dalam negeri yang termaktub dalam APBN dikurun waktu lima waktu terakhir. Jumlah penerimaan meningkat pada tiap tahunnya dan hanya mengalami penurunan pada tahun 2017, meskipun demikian tetap menjadi penyumbang terbesar dalam pendapatan negara. Berikut jumlah penerimaan dari perpajakan yang dapat disimak dalam tabel sebagai berikut :

Tabel 1. Pendapatan Negara dalam Negeri Indonesia Kurun Waktu 2013-2018

\begin{tabular}{|c|c|c|c|c|}
\hline Tahun & $\begin{array}{c}\text { Pendapatan } \\
\text { Negara } \\
\text { Dalam } \\
\text { Negeri }\end{array}$ & $\begin{array}{c}\text { Penerimaan } \\
\text { Perpajakan }\end{array}$ & $\begin{array}{c}\text { Penerimaan } \\
\text { Negara } \\
\text { Bukan Pajak }\end{array}$ & Hibah \\
\hline 2018 & $1.849,7$ & $1.618,1$ & 275,4 & 1,2 \\
\hline 2017 & $1.748,9$ & $1.498,9$ & 250,0 & 1,4 \\
\hline
\end{tabular}

${ }^{5}$ Ibid

${ }^{6}$ Sony Devano dan Siti Kurnia Rahayu, Perpajakan: Konsep, Teori, Isu. Kencana, Jakarta: 2006; hlm.102. 


\begin{tabular}{|l|l|l|l|l|}
\hline 2016 & $1.820,5$ & $1.546,7$ & 273,8 & 2,0 \\
\hline 2015 & $1.758,3$ & $1.489,2$ & 269,0 & 3,3 \\
\hline 2014 & $1.633,0$ & $1.246,1$ & 386,9 & 5,0 \\
\hline 2013 & 1525,2 & $1.193,0$ & 332,2 & 4,5 \\
\hline
\end{tabular}

Sumber : Hasil olah data APBN Indonesia Tahun 2013-2018

Data pertumbuhan penerimaan pajak menunjukkan progres penerimaan pajak secara positif, akan tetapi tidak cukup kuat untuk menopang beban anggaran belanja negara yang besar. Sehingga perlu upaya dalam rangka pemenuhan penerimaan pajak yang sesuai dengan kebutuhan negara. Maka untuk hal itu, pemerintah memikirkan beberapa terobosan dimana salah satunya adalah mulai melirik zakat sebagai sumber keuangan negara, pada awal tahun 2018 bahkan pemerintah berencana menerbitkan Peraturan Pemerintah berkenaan dengan penarikan zakat dari penghasilan Aparatur Sipil Negara.

Zakat dalam Pasal 1 Undang-Undang Nomor 23 Tahun 2011 tentang Pengelolaan Zakat didefinisikan sebagai "sebagai harta yang wajib dikeluarkan oleh seorang muslim atau badan usaha untuk diberikan kepada yang berhak menerimanya sesuai dengan syariat Islam. Penarikan zakat dilaksanakan oleh dua lembaga yakni Badan Amil Zakat yang didirikan oleh Pemerintah baik dalam ruang lingkup pusat hingga tingkat provinsi, kabupaten, dan kota disebut Badan Amil Zakat Nasional dan lembaga yang didirikan oleh masyarakat disebut Lembaga Amil Zakat. Terdapat asas-asas dalam pengelolaan zakat yakni : (1) syariat Islam; (2) amanah; (3) kemanfaatan; (4) keadilan; (5) kepastian hukum; (6) terintegrasi; dan (7) akuntabilitas. Dalam kehidupan bernegara di Indonesia pengaturan berkenaan tentang zakat diatur dalam peraturan perundang-undangan sebagai beriku:

a. Undang-Undang Nomor 23 Tahun 2011 tentang Pengelolaan Zakat;

b. Peraturan Pemerintah Nomor 60 Tahun 2010 tentang Zakat atau Sumbangan Keagamaan yang Sifatnya Wajib yang Boleh Dikurangkan dari Penghasilan Bruto;

c. Peraturan Pemerintah Nomor 14 Tahun 2014 tentang Pengelolaan Zakat;

d. Instruksi Presiden Nomor 3 Tahun 2014 Optimalisasi Pengumpulan Zakat di Kementerian/ Lembaga, Sekretariat Jenderal Lembaga Negara, Sekretariat Jenderal Komisi Negara, Pemerintah Daerah, Badan Usaha Milik Negara, Dan Badan Usaha Milik Daerah Melalui Badan Amil Zakat Nasional;

e. Peraturan Badan Amil Zakat Nasional Nomor 1 Tahun 2014 tentang Pedoman Tata Cara Pengajuan Pertimbangan Pengangkatan/ Pemberhentian Pimpinan Badan Amil Zakat Nasional Provinsi dan Badan Amil Zakat Nasional Kabupaten/ Kota;

f. Peraturan Badan Amil Zakat Nasional Nomor 2 Tahun 2014 tentang Pedoman Tata Cara Pemberian Rekomendasi Izin Pembentukan Lembaga Amil Zakat;

g. Peraturan Badan Amil Zakat Nasional Nomor 1 Tahun 2016 tentang Pedoman Penyusunan Rencana Kerja dan Anggaran Tahun Badan Amil Zakat Nasional, Badan Amil Zakat Nasional Provinsi, dan Badan Amil Zakat Nasional Kabupaten/Kota; 
h. Peraturan Badan Amil Zakat Nasional Nomor 2 Tahun 2016 tentang Pembentukan dan Tata Kerja Unit Pengumpulan Zakat.

Zakat juga diatur dalam Kompilasi Hukum Ekonomi Syariah yang tertuang dalam bentuk Peraturan Mahkamah Agung yakni Peraturan Mahkamah Agung Republik Indonesia Nomor 2 Tahun 2008 tentang Kompilasi Hukum Ekonomi Syariah (Buku I s/d IV) dimana Zakat disebut sebagai harta yang wajib disisihkan oleh seorang Muslim atau Lembaga untuk diberikan kepada yang berhak menerimanya. Kompilasi Hukum Ekonomi Syariah secara terperinci mengurai mayoritas jenis harta yang wajib dibayarkan zakat dimana mencakup zakat emas dan perak, zakat profesi, zakat pertanian, zakat perdagangan dan zakat fitrah. Kompilasi Hukum Ekonomi Syariah juga secara detail memuat aturan-aturan yang terkait dengan ketentuan umum zakat (Pasal 669), mustahik zakat (Pasal 682), amil zakat dalam hal ini disebut negara (Pasal 683), serta sanksi dan denda terkait zakat (Pasal 683).

\section{Integrasi Pajak dan Zakat}

Lahirnya gagasan integrasi pajak dan zakat tidak terlepas dari kondisi penduduk Indonesia yang mayoritas memeluk agama muslim. Besaran jumlah penganut adalah Islam sebesar 207.176.162 jiwa (87,18\%), Kristen Protestan sebesar 16.528.513 jiwa (6,96\%), Katolik sebesar 6.907,873 jiwa (2,91\%), Hindu sebesar 4.012.116 jiwa (1,69\%), Budha sebesar 1.703.254 jiwa (0,72\%), dan Kong $\mathrm{Hu} \mathrm{Cu}$ sebesar 117.091 jiwa $(0,05 \%)^{7}$. Gagasan Integrasi pajak dan zakat dapat dikatakan merupakan salah satu perwujudan transformasi hukum Islam sebagaimana dicitakan oleh Abdurrahman Wahid dimana hukum Islam harus mampu mengembangkan watak dinamis dengan menjadikan penunjang dalam transformasi hukum nasional di dalam pembangunan nasional ${ }^{8}$. Hukum Islam yang telah lama hidup dan berkembang dalam tatanan hukum nasional sebagaimana diketahui bahwa mayoritas penduduk Indonesia memeluk agama Islam.

Pada prinsipnya jika dikaji lebih mendalam terdapat persamaan dan perbedaan dari pajak dan zakat. Persamaan keduanya yakni kekuatan memaksa yang dimiliki serta melekat pada harta, pajak dan zakat juga memiliki kesamaan tujuan yakni dalam penyelesaian masalah ekonomi yang telah diatur agar dapat dikelola menurut cara yang dianggap tepat untuk mencapai tujuan, yaitu dengan menyetorkan pembayarannya ke lembaga resmi yang sudah disahkan pemerintah. Semuanya dikembalikan kepada batas minimum untuk dapat dikenakan kewajiban wajib bayar pajak dan zakat. Di pajak batas ini dikenal dengan istilah (penghasilan tidak kena pajak) dan nisbah terdapat pada zakat.

\footnotetext{
${ }^{7}$ Dickson, “Agama-Agama di Indonesia”, http://ilmupengetahuanumum.com/agama-agama-di-indonesia/, (Diakses pada 15/4/2018)

${ }^{8}$ Abdurrahman Wahid, Islam Kosmopolitan: Nilai-nilai Indonesia dan Transformasi Kebudayaan, The Wahid Institute, Jakarta: 2007; hlm.50.
} 
Perbedaan pajak dan zakat terdapat pada kewajiban membayar dimana zakat hanya dibebankan kepada kaum muslim atau pemeluk agama Islam. Maka zakat yang dikelola kemudian disalurkan kepada muslim yang membutuhkan, sedangkan pajak digunakan untuk belanja negara yang bersifat lebih umum seperti pembangunan infrastruktur, penyediaan fasilitas publik, dan lain sebagainya. "Zakat dibayarkan melalui amil zakat (lembaga penyalur dan pengelola zakat) maupun dibayarkan langsung kepada 8 golongan orang yang berhak menerima zakat. Manfaat zakat dapat dirasakan langsung maupun tidak langsung oleh masyarakat. Sedangkan pajak negara merupakan kewajiban yang dibayarkan kepada kantor pelayanan pajak dan lembaga-lembaga lain yang ditunjuk oleh Pemerintah sebagai tempat pembayaran pajak. Manfaat pajak negara tidak bisa dirasakan langsung oleh masyarakat dalam suatu negara".

Pajak dan zakat memiliki peran besar dalam penerimaan negara yang dapat digunakan sebagai sumber pembiayaan pembangunan nasional sebagaimana dapat disimak pada tabel dibawah ini :

\section{Tabel 2. Penerimaan Pajak di Indonesia dalam Kurun Lima Tahun Terakhir}

\begin{tabular}{|c|c|}
\hline Tahun & Jumlah (Triliun) \\
\hline 2013 & $1,193.00$ \\
\hline 2014 & $1,246.10$ \\
\hline 2015 & 1.489 .20 \\
\hline 2016 & $1,546.70$ \\
\hline 2017 & $1,498.90$ \\
\hline 2018 & $1,618.10$ \\
\hline
\end{tabular}

Sumber : Data diolah dari APBN Indonesia Tahun 2013-2018

Tabel 3. Penerimaan Zakat di Indonesia dalam Kurun Lima Tahun Terakhir

\begin{tabular}{|c|c|}
\hline Tahun & Jumlah (Triliun) \\
\hline 2011 & $1,729.00$ \\
\hline 2012 & $2,212.00$ \\
\hline 2013 & $2,639.00$ \\
\hline 2014 & $3,300.00$ \\
\hline 2015 & $3,650.00$ \\
\hline 2016 & $5,017.29$ \\
\hline
\end{tabular}

Sumber : Data dioleh dari Statistik Zakat Nasional Tahun 2011-2016

Pembiayaan pembangunan dalam arti luas adalah usaha pemerintah dalam menyediakan dana untuk membiayai pembangunan di wilayahnya dengan menggunakan sumber-sumber dari pendapatan (revenue), utang (debt), dan kekayaan (equity) yang bersifat konvensional atau non-konvensional. Pengertian ini memiliki implikasi bahwa pemerintah menyadari pembiayaan pembangunan tidak cukup hanya dari APBN/D saja. Sumber pembiayaan konvensional diperoleh dari pemerintah, yaitu dari anggaran pemerintah seperti APBN/APBD, pajak, retribusi. Sedangkan sumber pembiayaan nonkonvensional diperoleh dari gabungan dana pemerintah, swasta, dan masyarakat. Maka 
posisi zakat dalam sumber pembiayaan pembangunan nasional dapat dikategorikan dalam sumber pembiayaan non konvensional.

Integrasi zakat dan pajak dapat menjadikan penambahan sumber pembiayaan dimana terdapat hubungan saling melengkapi antara objek zakat dan pajak, mayoritas objek zakat yang tidak menjadi objek pajak begitu juga sebaliknya, sehingga masih banyak potensi penerimaan negara yang masih dapat digali dari hubungan antar objek ini. Maka pemerintah dapat meningkatkan penerimaan negaranya dengan meningkatkan upaya pemungutan zakat di masyarakat. Berkenaan dengan objek pajak dan zakat ini dapat dilihat dalam tabel sebagai berikut ${ }^{9}$ :

Tabel 4. Perbandingan Objek Pajak dan Zakat

\begin{tabular}{|c|c|c|}
\hline Jenis Objek & $\begin{array}{c}\text { Objek } \\
\text { Zakat }\end{array}$ & $\begin{array}{c}\text { Objek } \\
\text { Pajak }\end{array}$ \\
\hline Barang tambang dan hasil laut & $\sqrt{ }$ & $\sqrt{ }(\mathrm{PDRB})$ \\
\hline Investasi pabrik dan gedung & $\sqrt{ }$ & $\sqrt{ }(\mathrm{PBB})$ \\
\hline Penghasilan & $\sqrt{ }$ & $\sqrt{ }(\mathrm{PPh})$ \\
\hline Saham dan obligasi & $\sqrt{ }$ & $\mathrm{X}$ \\
\hline Pertambahan nilai & $\mathrm{x}$ & $\sqrt{ }(\mathrm{PPn})$ \\
\hline $\begin{array}{c}\text { Bumi dan bangunan selain pabrik dan } \\
\text { gedung }\end{array}$ & $\mathrm{x}$ & $\sqrt{ }(\mathrm{PBB})$ \\
\hline Penjualan barang mewah & $\mathrm{x}$ & $\sqrt{ }(\mathrm{PPn}-\mathrm{BM})$ \\
\hline Kendaraan bermotor & $\mathrm{x}$ & $\sqrt{ }(\mathrm{PDRD})$ \\
\hline Bahan bakar kendaraan bermotor & $\mathrm{x}$ & $\sqrt{ }(\mathrm{PDRD})$ \\
\hline Air permukaan & $\mathrm{x}$ & $\sqrt{ }(\mathrm{PDRD})$ \\
\hline Rokok & $\mathrm{x}$ & $\sqrt{ }(\mathrm{PDRD})$ \\
\hline Hotel & $\mathrm{x}$ & $\sqrt{ }(\mathrm{PDRD})$ \\
\hline Hiburan & $\mathrm{x}$ & $\sqrt{ }(\mathrm{PDRD})$ \\
\hline Reklame & $\mathrm{x}$ & $\sqrt{ }(\mathrm{PDRD})$ \\
\hline Penerangan jalan & $\mathrm{x}$ & $\sqrt{ }(\mathrm{PDRD})$ \\
\hline Air tanah & $\mathrm{x}$ & $\sqrt{ }(\mathrm{PDRD})$ \\
\hline Sarang burung walet & $\mathrm{x}$ & $\sqrt{ }(\mathrm{PDRD})$ \\
\hline
\end{tabular}

Sumber : Data diolah dari Muhammad Rheza Ramadhan

Setidaknya terdapat tiga pihak yang memberikan pendapat berkenaan dengan gagasan integrasi zakat dan pajak sebagai sumber keuangan negara, ketiga tokoh ini yakni MUI (Majelis Ulama Indonesia) Masdar Farid Mas'udi dan Didin Hafiddudin. MUI (Majelis Ulama Indonesia) selaku lembaga yang menangui masyarakat muslim di Indonesia, dalam pendapatnya bahwa terdapat pemisahan antara zakat dan pajak pada kewajiban untuk membayar kedua hal tersebut dengan logika bahwa zakat adalah kewajiban yang harus dijalankan atas Al-Qur'an dan Sunnah, berbeda dengan pajak

\footnotetext{
${ }^{9}$ Muhammad Rheza Ramadhan, “Integrasi Pajak dan Zakat di Indonesia”, Islamiconomic: Jurnal Ekonomi Islam,
} No.1, Vol.8, 2017, hlm.81. 
adalah kewajiban yang harus dijalankan atas dasar ketentuan pemerintah yang dibolehkan dalam ajaran Islam berdasarkan prinsip kemaslahatan masyarakat ${ }^{10}$.

Hal ini mengacu pendapat Abu Zahra yang mengatakan bahwa Zakat dan Pajak sebagai sesuatu yang berbeda dan tidak dapat disatukan. Zakat merupakan kewajiban yang sifatnya tetap, terus-menerus berlangsung berlaku sama ketentuan penghitungannya didasarkan dalam Al-Qur'an dan Sunnah, kewajiban zakat itu melekat pada setiap umat Islam di seluruh dunia. Sedangkan pajak terdapat ketentuan yang berbeda antara negara satu dengan lainnya yang ditetapkan dalam ketentuan perundang-undangan dan memiliki lembaga yang berwenang.

Faris Mas'udi berpendapat dalam bukunya Pajak dan Zakat bahwa pemisahan lembaga Pajak dan Zakat adalah suatu hal tidak benar karena konsep zakat merupakan konsep pajak, zakat sebagai ruhnya dan pajaknya sebagai badannya, dalam hal ini Masdar mengatakan bahwa orang yang membayar pajak harus diniatkan untuk membayar zakat, sehingga dapat diasumsikan bahwa umat Islam yang sudah membayar pajak tidak membayar zakat. Negara yang telah menerapkan ini adalah Kuwait, Pemerintah tidak membebankan pembayaran pajak kepada warga Kuwait dan memberlakukan pembayaran zakat secara Individu sesuai dengan ketentuan agama.

Didin Hafiudin berpendapat bahwa pembayaran zakat dianggap sebagai pengurangan zakat, terdapat dua pendapat dalam hal ini yakni : (1) kelompok yang berpendapat bahwa kebijakan zakat sebagai penghasilan bruto wajib pajak (tax deductible) seperti yang diterapkan saat ini. (2) kebijakan zakat sebagai penguran pajak secara langsung (tax credit) merupakan langkah strategis dalam upaya menggali potensi zakatm sekaligus mengintregasikan secara mendalam perekonomian nasional. Bahwa langkah ini menjadi alat redistribusi ekonomi yang efektif dimana menjadin aliran kekayaan dari kelompok kaya kepada kelompok miskin, selain itu memperluas manfaat wajib pajak dan muzakki, serta membantu meringankan beban Anggaran Penerimaan Belanja Negara dalam hal anggaran pengentasan kemiskinan.

Terdapat tiga model berkenaan dengan penarikan Zakat dan Pajak yang ditawarkan : (1) pembayaran Zakat dan Pajak menjadi dua hal yang berbeda dan tidak dapat disatukan; (2) pembayaran zakat melepaskan kewajiban kewajiban untuk membayar pajak; dan (3) pembayaran zakat membebankan pada pengurangan pembayaran pajak. Hal yang mayoritas diterapkan saat ini adalah ada model pertama dan beberapa lembaga maupun perusahaan menerapkan konsep model ketiga. Pada tahun 2018 pemerintah menawarkan penegasan kewajiban untuk membayar Zakat dan Pajak sebagai sumber keuangan Negara karena dalam praktiknya potensi zakat belum optimal.

\footnotetext{
${ }^{10}$ Zusiana Elly Triantini, "Integrasi Hukum Pajak Dan Zakat Di Indonesia Telaah Terhadap Pemikiran Masdar
} Farid Mas'udi”, Jurnal Al Ahkam. No. 23, Vol.23, 2012, hlm. 192. 
Berdasarkan karakteristik zakat yang telah dijelaskan diatas salah satu fungsi penting yakni sebagai pemerataan ekonomi melalui penyaluran harta dari kaya ke miskin. Maka perlu diupayakan integrasi zakat dapat digunakan dalam program-program pembangunan yang bertujuan untuk mengentaskan kemiskinan. Sehingga semua belanja modal dan belanja social pada Kementerian Pendidikan, Sosial, Kesehatan, UMKM dan Kesejahteraan Rakyat dapat dibiayai dari penerimaan zakat. Zakat disalurkan menjadi sumber pembiayaan dalam pembangunan nasional seperti :

a. Pendidikan melalui peningkatan sarana dan prasarana pendidikan seperti pembangunan dan rehabilitasi gedung-gedung sekolah, peningkatan kualitas guru pemberian beasiswa bagi keluarga miskin, dan peningkatan kualitas kurikulum pendidikan.

b. Kesehatan di prioritaskan dalam pembiayaan pembangunan unit kesehatan di daerahdaerah khususnya daerah terpencil dan daerah yang banyak terdapat masyarakat miskin melalui pencegahan, penganggulangan rawan gizi rendah.

c. Kemanusiaan difokuskan pada pembiayaan program tanggap darurat bencana, bantuan sosial, panti asuhan, panti jompo, dan panti-panti lainnya, serta yang dikelola dan bekerja sama dengan Kementerian Sosial dan Kementerian Bidang Kesejahteraan Rakyat.

d. Ekonomi mikro, difokuskan pada pembiayaan program-program dan pelatihan kewirausahaan, pengembangan dan pemberdayaan lembaga keuangan mikro,pengembangan usaha mikro, pemberdayaan kaum dhuafa atau masyarakat yang membutuhkan. Serta dibentuk kerja sama dengan pihak swasta dengan dibentuk : 1) Start-up business; 2) Masuknya Investor; 3) Penciptaan Lapangan Kerja.

Untuk lembaga yang berwenang berkenaan dengan integrasi pajak dan zakat sebagai sumber pembiayaan pembangunan nasional terdapat dua model yang dapat digunakan dengan keterkaitan penempatan zakat dalam APBN sebagai konsekuensi dari integrasi pajak dan zakat sebagai sumber keuangan. Lembaga/pihak yang berwenang dapat dilaksanakan dalam dua model, yakni : (1) pihak yang bertanggungjawab atas pemunggutan pajak dan zakat berada dalam sistem satu atap yakni dibawah kementerian keuangan sebagaimana diterapkan oleh Arab Saudi; dan (2) pihak yang bertanggungjawab atas pemunggutan pajak dan zakat berada pada dua lembaga sebagaimana diatur saat ini, dimana pajak berada dibawah kewenangan Direktorat Jendral Pajak dan zakat berada dibawah kewenangan Badan Amil Zakat Nasional dengan hubungan keterkaitan atau koordinasi yang dibangun keduannya.

Terlepas dari model yang diterapkan karena dibutuhkan kajian lebih mendalam berkenaan teknis pelaksanaan integrasi zakat dan pajak. Perlu dipahami bersama bahwa 
terdapat beberapa keuntungan yang ditawarkan dengan adanya integrasi zakat dan pajak sebagai sumber keuangan negara yakni ${ }^{11}$ :

a. Untuk menjamin dan kepastian dan disiplin pembayaran pajak dan zakat;

b. Menjaga perasaan rendah diri para mustahiq zakat apabila langsung menerima haknya dari para wajib zakat;

c. Untuk mencapai efektivitas, efisiensi, dan sasaran yang tepat guna optimalisasi zakat menurut skala prioritas;

d. Untuk mengamalkan nilai-nilai Islam dalam semangat penyelenggaraan negara dan pemerintah yang Islami;

e. Nilai dan manfaat zakat bisa menjadi dasar moral pengelolaan zakat dan pajak, sehingga menjauhkan akan terjadi korupsi dalam distribusi zakat dan meningkatan keimanan khususnya petugas pajak dan amil zakat.

\section{PENUTUP}

Potensi dari zakat sebagai sumber keuangan negara ini disadari oleh Kementerian Agama yang baru-baru ini muncul wacana untuk diadakan penarikan zakat penghasilan dari gaji Aparatur Sipil Negara (ASN), jika kebijakan ini diterapkan potensi dari zakat yang dikumpulkan mencapai Rp 10 triliun per tahun. Sementara, penerimaan zakat saat ini baru mencapai Rp 6 triliun dari potensi seluruh penerimaan zakat di negeri ini sebesar Rp 217 triliun. Wacana ini sebenarnya bukanlah hal baru, sejak 2014 telah diterbitkan Instruksi Presiden No.3 tahun 2014 tentang Optimalisasi Pengumpulan Zakat di Kementrian/Lembaga, Sekretariat Jenderal Lembaga Negara, Sekretariat Jenderal Komisi Negara, Pemerintah Daerah, Badan Usaha Milik Negara, Badan Usaha Milik Daerah melalui Baznas (Badan Amil Zakat Nasional).

Dengan integrasi zakat dan pajak dapat menjadikan penambahan sumber pembiayaan dimana terdapat hubungan saling melengkapi antara objek zakat dan pajak. Pajak dan zakat terdapat perbedaan peruntukan dimana penerima zakat harus seorang muslim. Maka zakat yang dikelola kemudian disalurkan kepada muslim yang membutuhkan, sedangkan pajak digunakan untuk belanja negara yang bersifat lebih umum seperti pembangunan infrastruktur, penyediaan fasilitas publik, dan lain sebagainya.

Setidaknya terdapat tiga model berkenaan dengan penarikan zakat dan pajak yang ditawarkan : 1. pembayaran zakat dan pajak menjadi dua hal yang berbeda dan tidak dapat disatukan; 2. pembayaran zakat melepaskan kewajiban untuk membayarkan pajak; dan 3. pembayaran zakat memberikan pengurangan beban dalam pembayaran pajak. Terdapat beberapa keuntungan yang ditawarkan dengan adanya integrasi zakat dan pajak sebagai sumber keuangan negara yakni : 1. untuk menjamin kepastian dan disiplin pembayar pajak dan zakat; 2. menjaga perasaan rendah diri para mustahiq zakat apabila langsung menerima

11 A. Muchaddam Fahham, "Paradigma Baru Pengelolaan Zakat diIndonesia", Jurnal Info Singkat Kesejahteraan Sosial. No.19, Vol.3, hlm.10 
haknya dari para wajib zakat; 3. untuk mencapai efisiensi, efektivitas, dan sasaran yang tepat dalam penggunaan harta zakat menurut skala prioritas yang ada pada suatu tempat; 4. untuk memperlihatkan syi'ar Islam dalam semangat penyelenggaraan negara dan pemerintahan yang Islami; 5. nilai transendental zakat bisa menjadi pegangan moral pengelola zakat dan pajak sehingga meminimalisir terjadinya korupsi dalam pengelolaan dan nepotisme dalam pendistribusian; dan 6. meningkatkan nilai keimanan masyarakat.

\section{DAFTAR PUSTAKA}

\section{Buku}

Abdurrahman Wahid, Islam Kosmopolitan: Nilai-nilai Indonesia dan Transformasi Kebudayaan, The Wahid Institute, Jakarta: 2007.

Edy suprianto, Hukum Pajak Indonesia, Yogyakarta: Graha Ilmu , 2014.

Sony Devano dan Siti Kurnia Rahayu, Perpajakan: Konsep, Teori, Isu. Kencana, Jakarta: 2006.

\section{Jurnal}

A. Muchaddam Fahham, "Paradigma Baru Pengelolaan Zakat diIndonesia", Jurnal Info Singkat Kesejahteraan Sosial. No.19, Vol.3.

Muhammad Rheza Ramadhan, "Integrasi Pajak dan Zakat di Indonesia", Islamiconomic: Jurnal Ekonomi Islam, No.1, Vol.8, 2017.

Zusiana Elly Triantini, "Integrasi Hukum Pajak Dan Zakat Di Indonesia Telaah Terhadap Pemikiran Masdar Farid Mas'udi”, Jurnal Al Ahkam. No. 23, Vol.23, 2012.

\section{Sumber Lainnya}

Dickson, "Agama-Agama di Indonesia", http://ilmupengetahuanumum.com/agama-agama-diindonesia/, (Diakses pada 15/4/2018)

Republika, "Ini Alasan Pemeirntah Pungut Langsung Zakat Gaji PNS Muslim", http://nasional.republika.co.id/berita/nasional/news-analysis/18/02/08/p3t4ig415-inialasan-pemerintah-pungut-langsung-zakat-gaji-pns-muslim (Diakses pada 15/4/2018)

Septian Deny, "Sri Mulyani Ingin Zakat Dikelola seperti Pajak", 2017 http://bisnis.liputan6.com/read/3068350/sri-mulyani-ingin-zakat-dikelola-sepertipajak, (Diakses pada 15/4/2018)

Serambi News, "Pajak Sumber APBN Terbesar",2017, http://aceh.tribunnews.com/2017/08/12/pajak-sumber-apbn-terbesar, (Diakses pada $15 / 4 / 2018)$ 